\title{
50-year return-period wet-snow load estimation based on weather station data for overhead line design in France
}

\author{
H. Ducloux ${ }^{1}$ and B. E. Nygaard ${ }^{2}$ \\ ${ }^{1}$ Réseau de Transport d'Electricité, Versailles, France \\ ${ }^{2}$ Kjeller Vindteknikk, Kjeller, Norway \\ Correspondence to: H. Ducloux (herve.ducloux@rte-france.com)
}

Received: 7 July 2014 - Published in Nat. Hazards Earth Syst. Sci. Discuss.: 14 August 2014

Revised: - - Accepted: 13 October 2014 - Published: 19 November 2014

\begin{abstract}
Historically, as far as wet-snow loads were concerned, overhead line design was often based on experience or long-term applications with positive results.

New standard like CENELEC EN 580341-1 (2012) take into account characteristic loads, i.e. 50-year return-period loads, for the overhead line design. This article proposes a method to estimate characteristic wet-snow loads based on meteorological data recorded at weather stations. The model used to calculate those loads is mainly inspired by a recent article written by Nygaard et al. (2013a) in which a new parameterization is proposed for the classical cylindrical wetsnow accretion model, as described in ISO 12494 standard (2001), annex C.

After a complete description of the model and its parameterization adapted to French wet-snow events, the statistical issues are examined. Then, the model is used with the meteorological data of 87 weather stations in order to calculate wet-snow loads whose relevance has been positively tested according to real damages recorded in a complete wet-snow event database.

At last, the characteristic loads of those 87 stations have been determined according to all the loads generated by the model and processed by a peak-over-threshold (POT) method.

A practical method to determine the $90 \%$ confidence intervals of those characteristic values is given. As it is demonstrated that there is only one value of the ice class (IC) masses proposed by ISO 12494 in each confidence interval, characteristic loads can be easily expressed in terms of ICs.

That method shows that ICs ranging from $\mathrm{R} 1\left(0.5 \mathrm{~kg} \mathrm{~m}^{-1}\right)$ to $\mathrm{R} 5\left(5 \mathrm{~kg} \mathrm{~m}^{-1}\right)$ could be used for overhead line design in France.
\end{abstract}

\section{Introduction}

Although the new CENELEC EN 50341-1 standard (2012 edition) proposes a complete method to calculate 50year wind loads on overhead line components, it only refers to ISO 12494 for wet-snow load determination, encouraging overhead line design engineers to use its ice classes (ICs) as 50-year loads. Unfortunately, direct statistical wet-snow load data are often poor or non-existent. Consequently, loads calculated with models using meteorological data are required in order to estimate 50-year return-period wet-snow loads.

A recent article by Nygaard et al. (2013a) proposes a new parameterization of the classical cylindrical wet-snow accretion model (described in ISO 12494, annex C) to be used with meteorological data simulated by the WRF model (Weather Research and Forecasting Model). This new parameterization has been successfully tested with real, severe and windy wet-snow cases in Iceland.

In the following sections, the authors propose a method to adapt the previous model to meteorological data recorded at weather stations instead of simulated data. They also propose a parameterization adapted to countries like France, where wet-snow events are less windy and less severe than those in Iceland. The uncertainty of wet-snow loads calculated in this way is given and a method to determine ISO ICs according to the calculated wet-snow loads is explained.

An example of the use of the method is given for French weather stations, and relevance of all obtained results is checked according to real French wet-snow events that have been recorded in a dedicated database for decades. 


\section{ISO 12494 classical wet-snow accretion model and its parameterization}

\subsection{Introduction to the model}

ICs can be determined based upon meteorological data together with the use of an ice accretion model, which is based on the classical equation given in the ISO annex:

$$
\frac{\mathrm{d} M}{\mathrm{~d} t}=\eta_{1} \eta_{2} \eta_{3} w A \boldsymbol{V} \text {. }
$$

$\mathrm{d} M$ is the linear mass density of snow accreted on the ISO reference collector during a small time $\mathrm{d} t ; \eta_{1} \eta_{2} \eta_{3}$ is the product of the collision, sticking and accretion efficiency factors; $w$ is the mass concentration of snowflakes in the atmosphere; $A$ is the cross-sectional area per unit length of the ISO reference collector with respect to the direction of the particle velocity vector $\boldsymbol{V}$.

As the ISO reference collector is a cylinder of the diameter $D_{0}$ slowly rotating around its axis, the mass accretion can be considered as having a cylindrical growth. Its diameter is $D$ and its linear mass density $M$ is determined according to the following basic equation:

$$
M=\frac{\pi \rho_{\mathrm{s}}}{4}\left(D^{2}-D_{0}^{2}\right)
$$

Assuming $\rho_{\mathrm{s}}$ (density of accreted snow) is constant during $\mathrm{d} t$, Eq. (2) can be transformed into Eq. (3):

$\frac{\mathrm{d} M}{\mathrm{~d} t}=\frac{\pi \rho_{\mathrm{s}}}{2} D \frac{\mathrm{d} D}{\mathrm{~d} t}$.

Combining Eqs. (1) and (3) and considering $e$ as the snow thickness $\left(D=D_{0}+2 e\right)$ and $D \times 1 \mathrm{~m}$ as $A$ leads to Eq. (4),

$\mathrm{d} e=\frac{\eta_{1} \eta_{2} \eta_{3} w \boldsymbol{V}}{\pi \rho_{\mathrm{s}}} \mathrm{d} t$

Finally, assuming all parameters are constant during one time step $\Delta t$ leads to

$$
\begin{aligned}
e(t+\Delta t)-e(t)= & \frac{\eta_{1} \eta_{2} \eta_{3} w \boldsymbol{V}}{\pi \rho_{\mathrm{s}}} \Delta t \\
M(t+\Delta t)-M(t) & =\frac{\pi \rho_{\mathrm{s}}}{4}\left(\left\{D_{0}+2 e(t+\Delta t)\right\}^{2}\right. \\
& \left.-\left\{D_{0}+2 e(t)\right\}^{2}\right)
\end{aligned}
$$

It is important to notice that $1 \mathrm{~m}$ of a real conductor compares very well with $1 \mathrm{~m}$ of the ISO reference collector as

- the height above ground level (a.g.l.) of a snow covered conductor of the distribution or low transmission overhead lines (90\% of French overhead lines) is close to $10 \mathrm{~m}$;

- the diameter of the ISO collector is close to the diameter of many conductors;

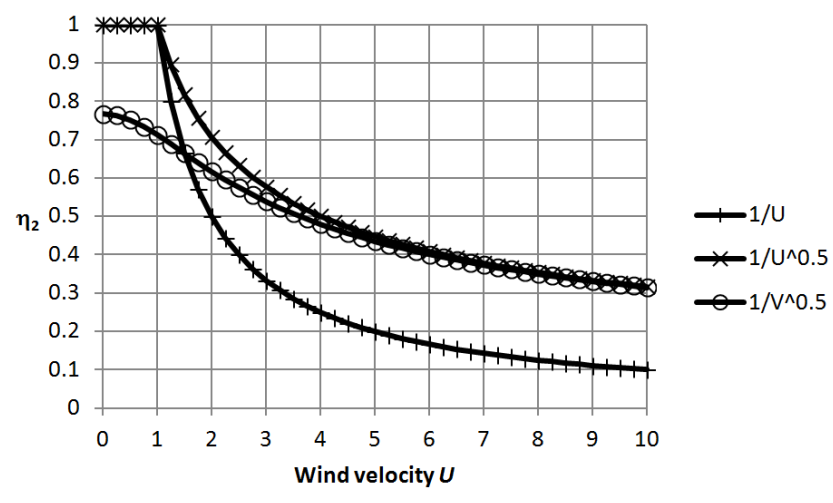

Figure 1. Sticking efficiency factor $\eta_{2}$, when $V_{\mathrm{t}}=1.7 \mathrm{~m} \mathrm{~s}^{-1}$.

- the torsion resistance of a conductor is such that it can slowly rotate around its axis everywhere but near its fixations or near spacers (in case of bundle conductors).

A key issue to address is the best parameter determination, which is discussed in the following sections. The idea is to stay as consistent as possible with ISO 12494 and to take into account the last model parameterization proposed by Nygaard et al. (2013a).

\subsection{Efficiency factors}

In most practical applications, the collision efficiency factor $\eta_{1}$ can be set to 1 in case of precipitation icing, like freezing rain or wet snow (ISO annex).

Historically, Admirat et al. (1988) noticed that the sticking efficiency factor $\eta_{2}$ depends strongly on the wind velocity $U$ and could be written according to Eq. (7):

$\eta_{2}=k \cdot U^{n}$

Nygaard et al. (2013a) and Elíasson et al. (2013) showed that the initial proposed parameterization (i.e. $k=1$ and $n=-1$ ) may lead to underestimated loads, especially in the case of windy events.

Nygaard et al. (2013a) proposed a modification, i.e. $k=1$ and $n=-0.5$, that has enabled them to obtain results consistent with real observations and to determine realistic 50-year wet-snow loads in Iceland.

As $\eta_{2}$ cannot be greater than 1 , it is usually set to 1 when $U$ is smaller than $1 \mathrm{~m} \mathrm{~s}^{-1}$, which generates a singular point for $\eta_{2}$ in function of $U$, as shown in Fig. 1 .

Another solution consists of using the snowflake velocity $V$ instead of the wind velocity $U . V$ is classically composed of the wind velocity $U$ and the terminal velocity $V_{\mathrm{t}}$ (vertical velocity) of the snowflake according to Eq. (8):

$V=\left(U^{2}+V_{\mathrm{t}}^{2}\right)^{0.5}$

As explained later, $V_{\mathrm{t}}$ is always greater than $1 \mathrm{~m} \mathrm{~s}^{-1}$, which means that $V$ is also greater than $1 \mathrm{~ms}^{-1}$ in any case and 
$\eta_{2}$ can never be greater than 1 . In the present study, $\eta_{2}$ is estimated according to Eq. (9):

$\eta_{2}=V^{-0.5}$

The accretion efficiency factor $\eta_{3}$ can be considered as a trigger: $\eta_{3}=1$ means that the accretion can start and/or continue, and $\eta_{3}=0$ means that snow cannot accrete.

As explained by Nygaard et al. (2013a), the liquid water fraction of the snow is the best parameter to determine if it can really accrete onto the collector. Unfortunately, that parameter is not measured routinely at weather stations.

According to Makkonen (1989), wet-bulb temperature $T_{\mathrm{wb}}$, which must be slightly greater than $0^{\circ} \mathrm{C}$ so as to allow flakes to be wet gently, is a good parameter to determine if the snow can stick. Nygaard et al. (2013a) noticed that $95 \%$ of the wet-snow cases occur at wet-bulb temperatures between 0 and $1{ }^{\circ} \mathrm{C}$.

In this study, as in Makkonen and Wichura (2010), one part of the wet-snow accretion criterion is $T_{\mathrm{wb}}$ greater than $-0.2^{\circ} \mathrm{C}$. As $T_{\mathrm{wb}}$ is not routinely recorded in all weather stations, the following criterion in Eq. (10) can be used to fix an equivalent lower limit to the relative humidity $(\mathrm{RH})$ in function of the air temperature $T_{\mathrm{a}}$ :

$\mathrm{RH}_{\text {low }}=96 \cdot \exp \left(-0.2 \cdot T_{\mathrm{a}}\right)$.

If $T_{\mathrm{wb}}$ is too high, precipitation may be rain instead of snow. Nygaard et al. (2013b) noticed that the upper limit for $T_{\mathrm{wb}}$ was slightly greater than $1{ }^{\circ} \mathrm{C}$ in case of wet-snow events and proposed to use $1.2^{\circ} \mathrm{C}$ as a practical upper limit. Makkonen (1989) proposed to use one of the Matsuo's statistical criteria (Matsuo et al., 1981) to determine the upper limit, which are almost equivalent to the previous ones. In this study, the following Matsuo's criterion in Eq. (11) is used:

$\mathrm{RH}_{\mathrm{up}}=39 \cdot\left(7.2-T_{\mathrm{a}}\right)^{0.5}$

As noticed by Wakahama (1979), no wet-snow cases have been recorded for air temperature above $2{ }^{\circ} \mathrm{C}$, which leads to the last criterion Eq. (12):

$T_{\mathrm{a}} \leq 2^{\circ} \mathrm{C}$.

As shown in Fig. 2, these three criteria draw a window in the plane formed by the air temperature and the relative humidity in which $\eta_{3}$ can be set to 1 .

\subsection{Mass concentration of snowflakes in the air}

One approach is to estimate the mass concentration $w$ from observed visibility $V_{\mathrm{m}}$ by a formula presented in Makkonen (1989). This approach has not been chosen by the authors, as visibility has not been widely recorded in the past 25 years at enough French weather stations. Furthermore, according to Rasmussen et al. (1999) in the chapter entitled "Comparison of observations with theory", the same visibility may lead to different snowfall rates.

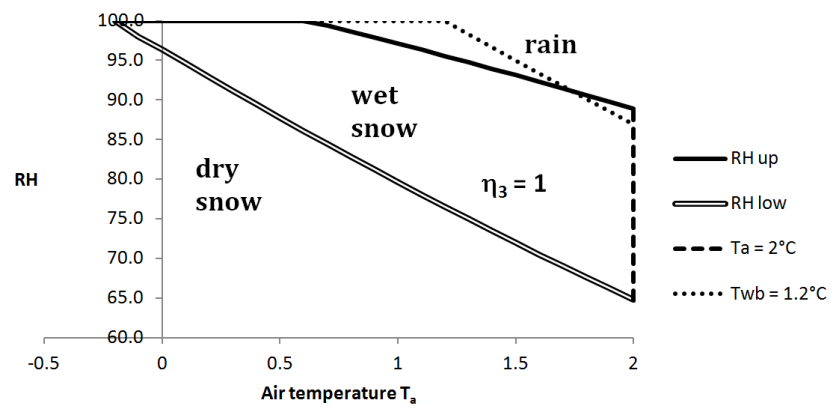

Figure 2. Wet-snow window $\left(\eta_{3}=1\right)$ in the air temperature $\left(T_{\mathrm{a}}\right)$ and relative humidity $(\mathrm{RH})$ plane.

"Under rapidly changing conditions, visibility is an unreliable indicator of snowfall intensity, unless crystal types and degree of riming and aggregation are known in real time" (Rasmussen et al., 1999).

As the equivalent water precipitation intensity $P$ is automatically recorded in many weather stations, Eq. (13) has been chosen by the authors to determine $w$.

$w=\frac{P}{V_{\mathrm{t}}}$

Terminal velocity can depend on the riming degree of snowflakes (Böhm, 1989; Barthazy and Schefold, 2006), as well as temperature (Muramoto et al., 1993; Yuter et al., 2006; Zawadski et al., 2010) or the height of the snow system (Zawadski et al., 2010).

All studies show that wet-snow terminal velocity is greater than $1 \mathrm{~m} \mathrm{~s}^{-1}$, which is generally considered as suitable to describe dry-snow terminal velocity. Based on the work of Yuter et al. (2006), Nygaard et al. (2013a) set $V_{\mathrm{t}}$ to $1.7 \mathrm{~m} \mathrm{~s}^{-1}$, which is the value used in this study as an average value for wet-snow terminal velocity.

In France, the intensity of precipitation is recorded by unshielded gauge (Leroy, 2002), which means that the catch ratio of precipitation is smaller than 1 as soon as the wind is blowing (Goodison, 1978; Rasmussen et al., 2012).

Some catch ratio (CR), given in \%, formulae are given in Goodison et al. (1998) for snow (freezing temperature) or mixed precipitation recorded by unshielded gauges. As this study is about wet-snow fall, the following formula in Eq. (14), intended for mixed precipitation, has been chosen:

$\mathrm{CR}=96.63+0.41 \cdot W^{2}-9.84 \cdot W+5.95 \cdot T_{\mathrm{a}}$,

where $W$ is the wind velocity at gauge height, which is roughly $70 \%$ of the wind velocity $U$ recorded at $10 \mathrm{~m}$ a.g.l. according to the method proposed in Goodison et al. (1998).

Therefore, the multiplicative correction factor $c$ for the intensity of precipitation $P$ is

$c=100 / \mathrm{CR}$. 
It must be underlined that Eq. (14) is valid for the Hellmann gauge, which is not used in France. Unfortunately, no such equation has been developed for typical unshielded French gauges. As the effect of the wind cannot be neglected, the authors have decided to use Eq. (14), assuming it is the best default option.

\subsection{Density of the accreted snow}

Nygaard et al. (2013a) used a fixed value of $700 \mathrm{~kg} \mathrm{~m}^{-3}$, which was well correlated with the Icelandic wet-snow case observation published by Elíasson et al. (2000) for windy events; i.e. wind velocity ranges from 10 to $25 \mathrm{~m} \mathrm{~s}^{-1}$.

As Strauss and Magnan (1985) noticed that wind velocity ranged from 0 to $10 \mathrm{~m} \mathrm{~s}^{-1}$ in more than $90 \%$ of French wet-snow cases recorded between 1949 and 1982, the fixed value of $700 \mathrm{~kg} \mathrm{~m}^{-3}$ cannot be used to study French wetsnow cases.

Deneau and Guillot (1984) estimated that the density of French wet-snow cases ranges from 300 to $500 \mathrm{~kg} \mathrm{~m}^{-3}$ for wind velocity varying from 0 to $8 \mathrm{~m} \mathrm{~s}^{-1}$.

As this study is intended to determine 50-year returnperiod wet-snow loads in France, the reasonable constant value of $400 \mathrm{~kg} \mathrm{~m}^{-3}$ proposed in the ISO annex for wet-snow density $\rho_{\mathrm{s}}$ is adopted.

\subsection{Shedding: end of event}

In regions like French plains (below an altitude of $500 \mathrm{~m}$ ), at the end of a wet-snow fall, temperature usually increases and snow turns to rain, which initiates the shedding. This is not true for mountain areas in which temperatures can drop after a wet-snow fall, which freezes the accretion.

In this study, the end of an event is characterized by a snow load that doesn't increase for at least 5 consecutive hours. That criterion is only available for French plains or equivalent areas. In that case, accreted snow load is reset and the event is reconsidered. Another criterion must be elaborated for such non-equivalent areas as mountains.

\section{Statistical aspects of the wet-snow load determination}

\subsection{Uncertainty estimation for one specific event}

As soon as $\eta_{3}$ is equal to 1 , the wet-snow accretion load depends on two recorded values, i.e. $P$ and $U$, the duration and four parameters, i.e. $V_{\mathrm{t}}, \rho_{\mathrm{s}}, n$ (which leads to $\eta_{2}$ ) and $\mathrm{CR}$ (which leads to $c$ ).

In order to estimate the uncertainty of the model, the random aspect of those four parameters must be addressed.

A normal distribution of those parameters is assumed, considering that

- $V_{\mathrm{t}}=1.7 \mathrm{~m} \mathrm{~s}^{-1}, \rho_{\mathrm{s}}=400 \mathrm{~kg} \mathrm{~m}^{-3}, n=-0.5$ and CR, calculated according to Eq. (14) (with $T_{\mathrm{a}}=0.5^{\circ} \mathrm{C}$ ), are reasonable mean values;
- $10 \%$ is the coefficient of variation for $V_{t}(99 \%$ of the values can range from 1.3 to $2.1 \mathrm{~m} \mathrm{~s}^{-1}$ );

- $10 \%$ is the coefficient of variation for $\rho_{\mathrm{s}}(99 \%$ of the values can range from 300 to $500 \mathrm{~kg} \mathrm{~m}^{-3}$ );

- $10 \%$ is the coefficient of variation for $n(95 \%$ of the values can range from -0.4 to -0.6 );

- $15 \%$ is the coefficient of variation for CR (from Goodison et al., 1998).

In all, 200000 random trials composed of 10 different fixed couples $(P \cdot t, U)$ associated with 20000 random sets of parameters $\left(V_{\mathrm{t}}, \rho_{\mathrm{s}}, n, \mathrm{CR}\right)$ have been carried out, and the main results of those simulations are presented in Table 1.

From a practical point of view, the following can be noticed:

- The calculated linear mass value $\left(M_{\mathrm{cal}}\right)$, directly estimated according to the model described in Sect. 2 with the mean values of the four parameters, corresponds to the median value of the distribution of each set of 20000 random trials.

- The mean linear mass $\left(M_{\text {mean }}\right)$ is $10 \%$ greater than the calculated linear mass $\left(M_{\mathrm{cal}}\right)$ and the corresponding coefficient of variation (CV) is $35 \%$.

- The $90 \%$ confidence interval is easily determined using the following simple rule: [60\% of the calculated linear mass $\left(M_{\mathrm{cal}}\right)-180 \%$ of the calculated linear mass $\left.\left(M_{\text {cal }}\right)\right]$.

For instance, when the calculation with the mean values of the parameters leads to $3.5 \mathrm{~kg} \mathrm{~m}^{-1}$ for one specific event, it can be reasonably considered that the wet-snow load is a random variable whose

- median value is $3.5 \mathrm{~kg} \mathrm{~m}^{-1}$;

- mean value is $1.1 \times 3.5 \mathrm{~kg} \mathrm{~m}^{-1}=3.8 \mathrm{~kg} \mathrm{~m}^{-1}$;

$-90 \% \quad$ confidence interval
$\left[0.6 \times 3.5 \mathrm{~kg} \mathrm{~m}^{-1}-1.8 \times 3.5 \mathrm{~kg} \mathrm{~m}^{-1}\right]$
$\left[2.1 \mathrm{~kg} \mathrm{~m}^{-1}-6.3 \mathrm{~kg} \mathrm{~m}^{-1}\right]$ is or

A simple distribution that fits reasonably well with the outcomes presented in Table 1 is required in the next section.

The authors suggest using a $\Gamma$ distribution whose classical parameters are

$$
\begin{aligned}
& -\alpha=1 / 0.35^{2} \\
& -\beta=1.1 \times 0.35^{2} \times M_{\mathrm{cal}} .
\end{aligned}
$$


Table 1. Main results of the 200000 random trials composed of 10 different fixed couples $(P \cdot t, U)$ associated with 20000 random sets of parameters $\left(V_{\mathrm{t}}, \rho_{\mathrm{s}}, n, \mathrm{CR}\right)$.

\begin{tabular}{|c|c|c|c|c|c|c|c|c|}
\hline $\begin{array}{l}P \cdot t \\
(\mathrm{~mm})\end{array}$ & $\begin{array}{c}U \\
\left(\mathrm{~m} \mathrm{~s}^{-1}\right)\end{array}$ & $\begin{array}{c}M_{\mathrm{cal}} \\
\left(\mathrm{kg} \mathrm{m}^{-1}\right)\end{array}$ & $\begin{array}{c}M_{\text {mean }} \\
\left(\mathrm{kg} \mathrm{m}^{-1}\right)\end{array}$ & $M_{\text {mean }} / M_{\mathrm{cal}}$ & $\mathrm{CV}$ & $M_{5 \%} / M_{\mathrm{cal}}$ & $M_{50 \%} / M_{\mathrm{cal}}$ & $M_{95 \%} / M_{\mathrm{cal}}$ \\
\hline 20 & 2 & 1.05 & 1.11 & 1.07 & $28 \%$ & 0.70 & 1.01 & 1.60 \\
\hline 40 & 2 & 2.86 & 3.08 & 1.08 & $31 \%$ & 0.67 & 1.01 & 1.70 \\
\hline 60 & 2 & 5.45 & 5.92 & 1.09 & $33 \%$ & 0.65 & 1.02 & 1.74 \\
\hline 80 & 2 & 8.80 & 9.62 & 1.09 & $35 \%$ & 0.64 & 1.02 & 1.80 \\
\hline 20 & 5 & 2.34 & 2.54 & 1.09 & $34 \%$ & 0.65 & 1.02 & 1.77 \\
\hline 30 & 5 & 4.39 & 4.83 & 1.10 & $36 \%$ & 0.63 & 1.02 & 1.86 \\
\hline 40 & 5 & 7.03 & 7.77 & 1.10 & $38 \%$ & 0.61 & 1.01 & 1.89 \\
\hline 10 & 8 & 1.56 & 1.70 & 1.08 & $34 \%$ & 0.63 & 1.02 & 1.76 \\
\hline 20 & 8 & 4.50 & 4.96 & 1.10 & $39 \%$ & 0.60 & 1.02 & 1.88 \\
\hline 30 & 8 & 8.80 & 9.82 & 1.12 & $41 \%$ & 0.59 & 1.02 & 1.96 \\
\hline \multirow{2}{*}{\multicolumn{4}{|c|}{$\begin{array}{l}\text { Arithmetic mean values } \\
\text { Rounded values }\end{array}$}} & 1.09 & $35 \%$ & 0.64 & 1.02 & 1.80 \\
\hline & & & & 1.1 & $35 \%$ & 0.6 & 1 & 1.8 \\
\hline
\end{tabular}

\subsection{0-year return-period wet-snow load determination}

Data from weather stations that have been recorded for years are processed according to the classical wet-snow accretion model and the parameterization proposed in this study.

In so doing, wet-snow events are isolated for each station and processed according to a peak-over-threshold (POT) method to evaluate the 50-year return-period wet-snow loads of the weather station area.

Generalized Pareto distribution (GPD) parameters of the POT method are evaluated according to the L-Moment method, as proposed by Hosking (1990).

In so doing, what is hereafter referred to as the "calculated value" of the 50-year return-period wet-snow load is obtained.

In order to calculate the mean value and the $90 \%$ confidence interval of the 50-year return-period wet-snow load, the wet-snow load of each individual event is considered as being a random variable distributed according to the previously described $\Gamma$ distribution.

In all, 10000 numerical simulations for four representative weather stations of different areas in France (Lille, Chartres, Carcassonne and Grenoble) have shown that the 50-year return-period wet-snow load is well represented by a normal distribution whose mean value is 1.11 times greater than the calculated value and whose coefficient of variation is $17 \%$. Thus, the $90 \%$ confidence interval is [ $80 \%$ of the calculated value $-142 \%$ of the calculated value].

To determine the ISO Ice Classes, the authors suggest using the following practical interval: $[79 \%$ of the calculated value $-141 \%$ of the calculated value].

These precise values have been chosen because

- they are rather consistent with the normal distribution described above;
- it can be shown that one and only one ISO IC value (Table 4 of ISO 12494) can be found in such a confidence interval.

One way to show this uniqueness is simply to notice that using the multiplicative factor $1.41 / 0.79=1.78$ allows one to move from one ISO IC value to the next, as illustrated by the following examples:

$$
\begin{aligned}
& -1.6 \mathrm{~kg} \mathrm{~m}^{-1} \text { (R3) is equal to } 1.78 \times 0.9 \mathrm{~kg} \mathrm{~m}^{-1}(\mathrm{R} 2) \text {; } \\
& -8.9 \mathrm{~kg} \mathrm{~m}^{-1} \text { (R6) is equal to } 1.78 \times 5 \mathrm{~kg} \mathrm{~m}^{-1}(\mathrm{R} 5) \text {. }
\end{aligned}
$$

For instance, when the calculated value of the 50-year returnperiod wet-snow load for one station is $4 \mathrm{~kg} \mathrm{~m}^{-1}$, the mean 50 -year return-period load is $4.4 \mathrm{~kg} \mathrm{~m}^{-1}$ and the $90 \%$ confidence interval of the 50 -year return-period wet-snow load is $\left[3.2-5.6 \mathrm{~kg} \mathrm{~m}^{-1}\right]$.

The only IC value that can be found in this interval is $5 \mathrm{~kg} \mathrm{~m}^{-1}$. Therefore, it is suggested that one considers ISO IC R5 as being suitable for that example.

\section{Application to the French wet-snow cases}

\subsection{French wet-snow design rules}

Design rules accounting for wet-snow loads established before 1950 are unknown. From a legal point of view, wind load and contraction due to freezing temperatures were the only meteorological resistance obligations.

From 1950 to 1985, with the creation of the national company Electricité de France (EDF), design rules became clearer. Describing these rules in terms of ISO and its reference collector, the following can be considered:

- plains on the Atlantic side of the country (north and west) were not concerned by wet-snow loads; 
- others plains were concerned by loads of $2 \mathrm{~kg} \mathrm{~m}^{-1}$;

- mountains were concerned by loads of $5 \mathrm{~kg} \mathrm{~m}^{-1}$ or even $10 \mathrm{~kg} \mathrm{~m}^{-1}$ of accreted snow or rime.

In 1987, due to some successive and memorable damageable wet-snow events, design rules were modified as follows:

- all plains were concerned by $2 \mathrm{~kg} \mathrm{~m}^{-1}$;

- specific plains in the southern part of the country were concerned by $5 \mathrm{~kg} \mathrm{~m}^{-1}$;

- design rules in the mountain area were unchanged.

Since 1971, French accretion design rules have been described according to a thickness of accretion (snow, rime or glaze), i.e. 2,4 or $6 \mathrm{~cm}$, associated with a unique density of $600 \mathrm{~kg} \mathrm{~m}^{-3}$, which are the equivalent of 2,5 and $10 \mathrm{~kg} \mathrm{~m}^{-1}$, respectively, onto the ISO reference collector.

For a pole and lattice tower design, symmetric and asymmetric ice loads on conductors combined with small wind loads (180 Pa on rimed conductors) are taken into account.

These design rules have never been changed for new overhead lines since 1987.

It is important to underline the fact that all the lines designed according to $5 \mathrm{~kg} \mathrm{~m}^{-1}$ ( $4 \mathrm{~cm}$ of an accreted snow of density $600 \mathrm{~kg} \mathrm{~m}^{-3}$ ) have never been damaged by any wetsnow events in specific plains since their construction.

\subsection{Chosen weather stations}

The model described in Sect. 2 and the statistical approach described in Sect. 3 have been used with recorded data from 82 French weather stations well distributed all over the country.

Those stations have been selected according to the four following criteria:

1. Data continually recorded for 25 years since the winter of $1989 / 1990$.

- 25-year period is considered by the authors as a minimum to estimate 50-year return-period loads.

- It is assumed that a 25-year period is long enough to reflect the normal variability in local weather, yet short enough not to be influenced significantly by any long-term trends in climate.

2. Altitude smaller than $500 \mathrm{~m}$.

- Above $500 \mathrm{~m}$, the criterion chosen to consider that the event is over (shedding) cannot be considered as being usable (see Sect. 2.5).

- The main focus of this study is the wet-snow loads in French plains at low altitude, which represent about $80 \%$ of the territory.
3. Normal environmental situation.

- Stations located on areas highly influenced by orography have not been chosen (for instance, stations upon cliffs).

4. Good data quality.

- Air temperature, relative humidity, intensity of precipitation and wind velocity have to be recorded every 3 hours or less.

Five others stations at an altitude greater than $500 \mathrm{~m}$, i.e. Aurillac $(640 \mathrm{~m})$, Millau $(720 \mathrm{~m})$, Le Puy (833 m), Bourg-StMaurice $(868 \mathrm{~m})$ and Embrun $(876 \mathrm{~m})$, are added to this study in order to test the model parameterization in areas above $500 \mathrm{~m}$.

\subsection{Results of the calculation for the last 25 winters}

According to the data of the 87 selected weather stations, 170 events with a load equal to or greater than $1 \mathrm{~kg} \mathrm{~m}^{-1}$ were simulated by the model proposed in Sect. 2 .

During the last 25 winters, eight real events were considered as noticeable (large area concerned by wet-snow damages and/or collapsed poles or towers), and internal reports were produced.

All those noticeable events have been well simulated by the model; i.e. good localizations, good dates and calculated loads consistent with the real damages, taking into account the overhead line design, as described in Sect. 4.1.

When an event cannot be associated with more than one collapsed pole or tower, or when an event concerns a small area, no internal report is produced. Nevertheless, the event is recorded in a database, which is used in the following paragraphs.

As explained in Sect. 4.2, 5 out of the 87 stations of that study $(6 \%)$ are located at an altitude greater than $500 \mathrm{~m}$. Those stations are concerned by 37 out of the 170 events (22\%) with a load equal to or greater than $1 \mathrm{~kg} \mathrm{~m}^{-1}$. Few of those 37 events can be related to real damages because the design loads in these kinds of regions have already taken into account heavy wet-snow and rime loads for a long time; i.e. 5 or even $10 \mathrm{~kg} \mathrm{~m}^{-1}$.

The remaining 133 events concern plains at an altitude below $500 \mathrm{~m}$, where wet-snow loads have not been taken into account in the design of overhead lines, or have been taken into account according to a value of about $2 \mathrm{~kg} \mathrm{~m}^{-1}$.

Those 133 simulated events have been distributed into four classes: more than $3 \mathrm{~kg} \mathrm{~m}^{-1}$ (14 cases), between 2 and $3 \mathrm{~kg} \mathrm{~m}^{-1}$ (27 cases), between 1.5 and $2 \mathrm{~kg} \mathrm{~m}^{-1}$ (25 cases) and between 1 and $1.5 \mathrm{~kg} \mathrm{~m}^{-1}$ (67 cases).

When available, present weather (PW) codes were used to check if the criteria proposed in Sect. 2.2 were able to select real snow cases. In 37 out of 133 cases (28\%), PW showed that precipitation was rain or a mixture of rain (code 60 to 65) and snow (code 70 to 75 ), which means that it is likely that 
the precipitation was too wet to generate real wet-snow accretion events. This assumption is verified as no associated real events were found in the database. In this way, the model can be considered as being slightly conservative.

Nevertheless, as those meteorological conditions were very close to the optimal wet-snow conditions, it is suggested that one keeps all simulated loads to calculate the 50-year return-period wet-snow loads.

In the remaining 96 cases, 57 real recorded events $(60 \%)$ could be associated with calculated loads greater than $1 \mathrm{~kg} \mathrm{~m}^{-1}$. Details are summarized in Table 2 .

As expected, when the calculated load is greater than $2 \mathrm{~kg} \mathrm{~m}^{-1}$, which is the "normal" design load in plains, the proportion of real recorded events that can be found in the database is important $(90 \%)$. The worst simulated events, i.e. those with calculated loads greater than $5 \mathrm{~kg} \mathrm{~m}^{-1}$, generally concern real recorded events with collapsed towers and poles.

For calculated loads between 1 and $2 \mathrm{~kg} \mathrm{~m}^{-1}$, that proportion is smaller $(46 \%)$ but still consistent with the fact that

- calculated loads are median values as explained in Sect. 3.1;

- some overhead lines designed before 1987 were not supposed to resist loads up to $2 \mathrm{~kg} \mathrm{~m}^{-1}$.

Even if a calculated load is not sufficient enough to generate damage, it must be kept in order to have enough cases to calculate the 50-year return-period wet-snow loads according to the POT method, as presented in the next section.

\subsection{0-year return-period wet-snow loads according to POT method}

For each weather station, simulated wet-snow loads have been calculated according to the model described in Sect. 2 .

For instance, 241 loads have been calculated according to 187327 meteorological records in 25 years for the Lille station in the north of France.

Among these 241 loads represented on Fig. 3, only 22 are greater than a threshold of $0.3 \mathrm{~kg} \mathrm{~m}^{-1}$.

Using the L-Moment method as explained in Sect. 3.2, the GPD parameters of the POT method can be calculated and the 50-year return-period load determined.

In the case of Lille, that value is $2.55 \mathrm{~kg} \mathrm{~m}^{-1}$, which means that, according to the practical method described in Sect. 3.2, the mean 50 -year return-period load is $2.8 \mathrm{~kg} \mathrm{~m}^{-1}$ and the $90 \%$ confidence interval calculated is $\left[2-3.6 \mathrm{~kg} \mathrm{~m}^{-1}\right]$. Consequently, the ISO IC for Lille is R4.

The influence of the threshold is presented in Table 3. It can be noticed that

- the 50-year return-period value is very stable;

- the shape parameter of the GPD is always in the range [-0.5-0], which is the optimal range according to Hosking (1990).
In this study, the optimal choice of the threshold value for each station had generally led to a number of selected values corresponding to the $10 \%$ greatest values (generally around 25 values for the usual cases in France).

The case of Lille is also very interesting because of the highest calculated value $\left(3.2 \mathrm{~kg} \mathrm{~m}^{-1}\right)$ recorded in March 2012. As the 50-year return-period determination is highly influenced by the highest value, special attention must be paid to that case.

In two-thirds of the western and northern part of the country roughly located between the Atlantic side and the mountain areas, such a value, which has been associated with a real noticeable event (one $225 \mathrm{kV}$ collapsed tower and a dozen of $400 \mathrm{kV}$ damaged towers), is more than extremely rare.

For the Lille station, the second-biggest value is only $1.4 \mathrm{~kg} \mathrm{~m}^{-1}$, which is less than half of the biggest value.

In one background document of EN 1991-1-3, i.e. the final report produced by Sanpaolesi (1998) about snow load determination, one criterion for identifying "exceptional load" values is given:

"If the ratio of the largest load value to the characteristic load (50-year return-period load) determined without the inclusion of that value is greater than 1.5, then the largest load value shall be treated as an exceptional value (and not used in the determination of the 50-year return-period value)".

In the case of Lille, the mean 50-year return-period load determined without the largest value $\left(3.2 \mathrm{~kg} \mathrm{~m}^{-1}\right)$ is $1.8 \mathrm{~kg} \mathrm{~m}^{-1}$. As the ratio $3.2 / 1.8$ is greater than 1.5 , that value could be excluded and the new $90 \%$ confidence interval could be [1.2-2.4 $\left.\mathrm{kg} \mathrm{m}^{-1}\right]$ and the new ISO IC could be R3.

The above criterion for identifying exceptional load is still under discussion by the community (Sadovský et al., 2012; Kasperski, 2014). Therefore, the authors suggest using it only when the exceptional aspect of the value can be checked; i.e. according to a real event database. The Lille event of March 2012 can be considered as exceptional as it has been the second most serious event of that kind in a homogenous area as big as half of the country for 50 years.

For the 87 French weather stations, each ISO IC has been calculated (Table 4) without excluding the largest value, even when the criterion evocated above was positive. Results are presented in Fig. 4.

Each station is at the centre of a circle of $50 \mathrm{~km}$ in diameter and it may be not prudent to extrapolate what is calculated according to the data recorded at one specific station outside its associated circle, especially in the case of different valleys in mountainous areas.

\subsection{Comparisons with previous winter wet-snow events}

Real cases that affected the transmission network before 1987 are represented in an old internal EDF document produced by Mazingarbe (1987). All cases but one happened in 
Table 2. Study of the 133 cases of calculated loads greater than $1 \mathrm{~kg} \mathrm{~m}^{-1}$. PW: present weather.

\begin{tabular}{lccccr}
\hline Class & $\begin{array}{c}\text { Number } \\
\text { of cases }\end{array}$ & $\begin{array}{c}\text { PW code } \\
\text { rain or } \\
\text { rain and } \\
\text { snow }\end{array}$ & $\begin{array}{c}\text { Number } \\
\text { of snow } \\
\text { cases }\end{array}$ & $\begin{array}{c}\text { Number } \\
\text { of real } \\
\text { recorded } \\
\text { events }\end{array}$ & Proportion \\
\hline More than $3 \mathrm{~kg} \mathrm{~m}^{-1}$ & 14 & 1 & 13 & 13 & $100 \%$ \\
Between 2 and $3 \mathrm{~kg} \mathrm{~m}^{-1}$ & 27 & 11 & 16 & 13 & $81 \%$ \\
Between 1.5 and $2 \mathrm{~kg} \mathrm{~m}^{-1}$ & 25 & 6 & 19 & 12 & $63 \%$ \\
Between 1 and $1.5 \mathrm{~kg} \mathrm{~m}^{-1}$ & 67 & 19 & 48 & 19 & $40 \%$ \\
\hline Total & 133 & 37 & 96 & 57 & - \\
\hline
\end{tabular}

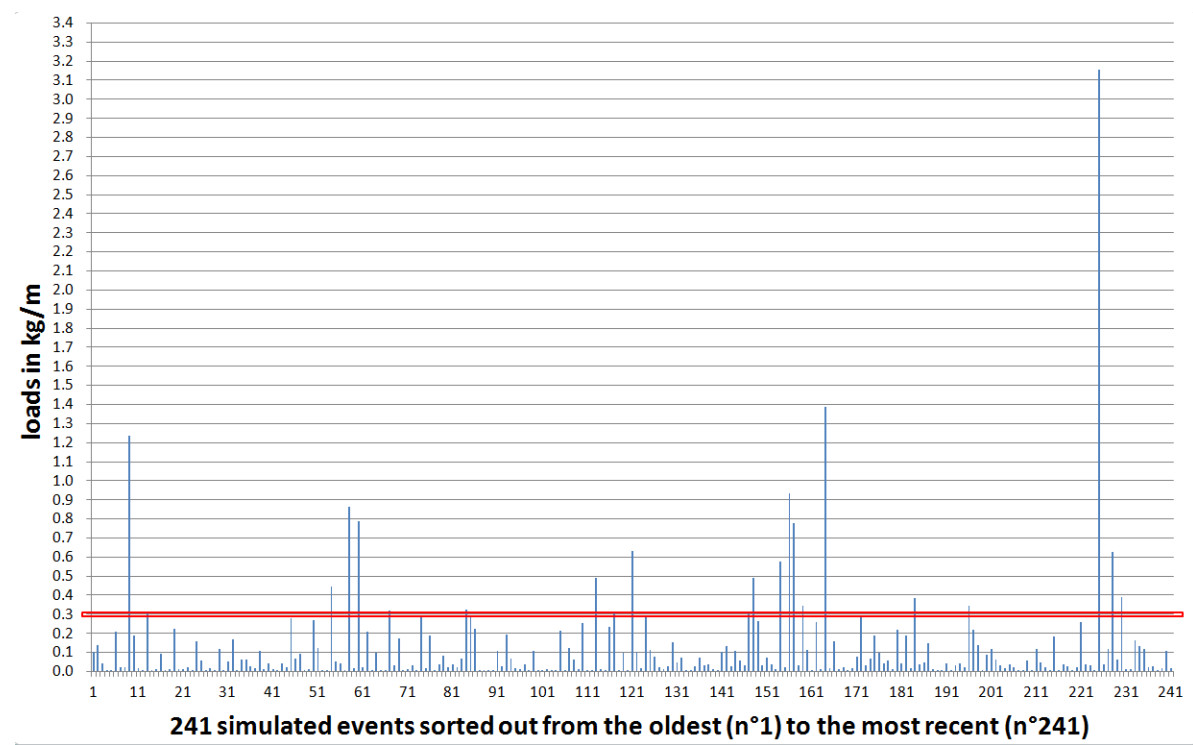

Figure 3. Calculated loads for the Lille weather station with $0.3 \mathrm{~kg} \mathrm{~m}^{-1}$ threshold (red line).

Table 3. Study of the 50-year return-period load for Lille in function of the threshold choice.

\begin{tabular}{lccc}
\hline Threshold $T$ & $\begin{array}{c}\text { Number of values } \\
\text { greater than } T\end{array}$ & $\begin{array}{c}\text { Shape parameter } \\
\text { of the GPD }\end{array}$ & $\begin{array}{c}50 \text {-year return } \\
\text { period value }\end{array}$ \\
\hline 0.1 & 74 & -0.46 & $2.54 \mathrm{~kg} \mathrm{~m}^{-1}$ \\
0.2 & 40 & -0.49 & $2.54 \mathrm{~kg} \mathrm{~m}^{-1}$ \\
0.3 & 22 & -0.49 & $2.55 \mathrm{~kg} \mathrm{~m}^{-1}$ \\
0.4 & 13 & -0.29 & $2.53 \mathrm{~kg} \mathrm{~m}^{-1}$ \\
0.5 & 10 & -0.31 & $2.54 \mathrm{~kg} \mathrm{~m}^{-1}$ \\
0.6 or more & Not enough values & - & - \\
\hline
\end{tabular}

the mountainous area or in the plains of the southern part of the country, as shown in Fig. 5.

As expected, few events are recorded in the Alps, as overhead lines have already been designed with heavy loads in this area for many years.

In the western part of the Mediterranean coast (Perpignan), severe events happened in 1981 and 1986, which is consistent with what can be estimated according to the data of the last 25 winters:

- another noticeable event (many collapsed towers) happened in the same area in 1992;

- one of the biggest 50-year return-period loads in France for Perpignan (ISO IC R5).

In the region of the Rhône Valley, severe events also happened in 1970, 1974 and 1982. As expected, many stations along that valley are concerned by an important ISO IC, i.e. R4 and R5, compared to the western or northern part of France; i.e. mainly R1, R2 or R3.

The same conclusions can be drawn for the foothills of the Pyrenees:

- a lot of events were recorded before 1987;

- there was a very noticeable event in January 1997 in the same area (damaged and broken earth wires and conductors, damaged or collapsed poles or towers); 


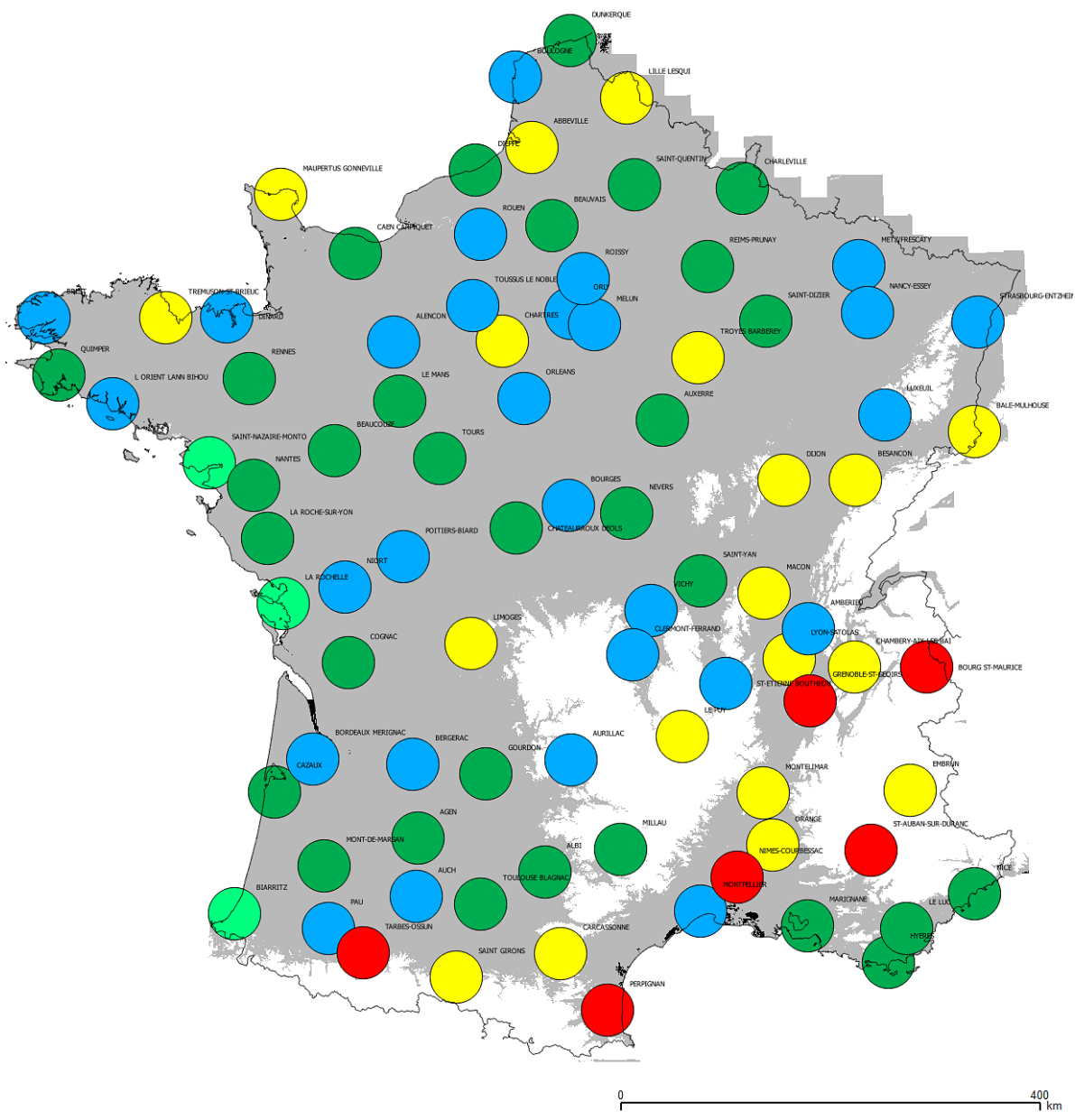

Figure 4. ISO ICs for the 87 French weather stations of the study (pale green: R1; dark green: R2; blue: R3; yellow: R4; red: R5; white area: area above $500 \mathrm{~m})$.

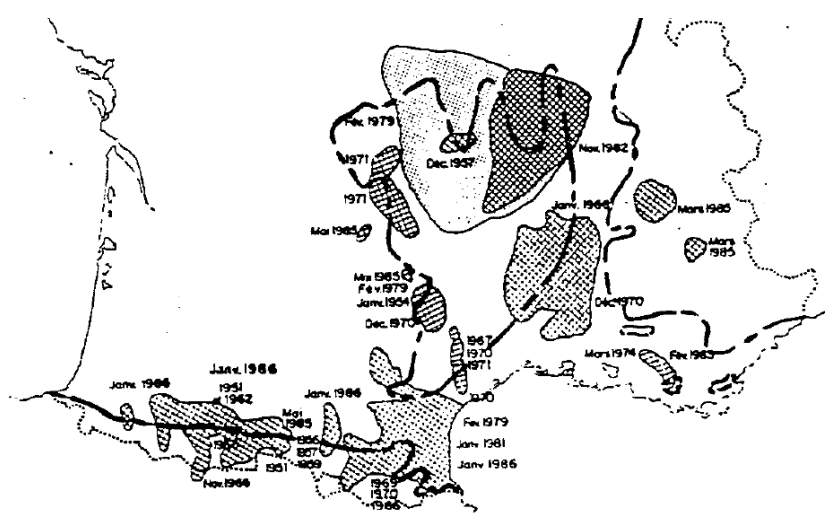

Figure 5. Areas concerned by wet-snow events before 1987.

- one of the biggest 50-year return-period loads in France for Tarbes (ISO IC R5).
Thus, it can be considered that the analysis of the last 25 winters, according to the model proposed in Sect. 2, is consistent with what happened during previous winters.

\section{Conclusions}

Two modifications of the parameterization proposed by $\mathrm{Ny}$ gaard et al. (2013a) for the conventional cylindrical wet-snow accretion model have been introduced:

- reduced mean value of the accretion density more adapted to the small wind velocity during French wetsnow precipitations;

- estimation of mass concentration of snowflakes in the atmosphere according to the wind-effect corrected in tensity of precipitation recorded in French weather stations.

Taking into account the original wet-snow load design of French overhead lines, the new model has allowed the 
Table 4. 87 French weather stations with their names, altitudes, $90 \%$ confidence intervals and ISO ICs.

\begin{tabular}{|c|c|c|c|c|c|c|c|c|c|}
\hline \multirow[t]{2}{*}{ Station name } & \multirow[t]{2}{*}{ Altitude } & \multicolumn{2}{|c|}{$\begin{array}{c}90 \% \text { confidence } \\
\text { interval }\end{array}$} & \multirow[t]{2}{*}{ ISO IC } & \multirow[t]{2}{*}{ Station name } & \multirow[t]{2}{*}{ Altitude } & \multicolumn{2}{|c|}{$\begin{array}{c}90 \% \text { confidence } \\
\text { interval }\end{array}$} & \multirow[t]{2}{*}{ ISO IC } \\
\hline & & $M-$ & $M+$ & & & & $M-$ & $M+$ & \\
\hline AGEN & 60 & 0.6 & 1.0 & $\mathrm{R} 2$ & LYON-SATOLAS & 240 & 2.0 & 3.5 & $\mathrm{R} 4$ \\
\hline ALBI & 176 & 0.7 & 1.3 & $\mathrm{R} 2$ & MACON & 217 & 1.7 & 3.0 & $\mathrm{R} 4$ \\
\hline ALENCON & 144 & 1.1 & 2.0 & R3 & MARIGNANE & 32 & 0.6 & 1.0 & $\mathrm{R} 2$ \\
\hline AURILLAC & 640 & 1.3 & 2.3 & R3 & METZ/FRESCATY & 192 & 1.2 & 2.1 & R3 \\
\hline AUXERRE & 212 & 0.7 & 1.3 & $\mathrm{R} 2$ & MILLAU & 720 & 0.8 & 1.4 & $\mathrm{R} 2$ \\
\hline BALE-MULHOUSE & 273 & 2.1 & 3.8 & $\mathrm{R} 4$ & MONT-DE-MARSAN & 60 & 0.9 & 1.6 & $\mathrm{R} 2$ \\
\hline BEAUCOUZE & 50 & 0.7 & 1.3 & $\mathrm{R} 2$ & MONTELIMAR & 74 & 2.4 & 4.2 & $\mathrm{R} 4$ \\
\hline BEAUVAIS & 111 & 0.6 & 1.1 & $\mathrm{R} 2$ & MONTPELLIER & 8 & 0.9 & 1.7 & R3 \\
\hline BERGERAC & 51 & 1.2 & 2.1 & R3 & NANCY-ESSEY & 212 & 1.4 & 2.5 & R3 \\
\hline BOURG ST-MAURICE & 868 & 3.8 & 6.8 & R5 & NIORT & 61 & 1.5 & 2.7 & $\mathrm{R} 3$ \\
\hline BOURGES & 166 & 1.0 & 1.8 & R3 & ORANGE & 55 & 1.8 & 3.2 & $\mathrm{R} 4$ \\
\hline BREST & 99 & 1.2 & 2.1 & R3 & ORLEANS & 125 & 1.3 & 2.4 & R3 \\
\hline CAEN CARPIQUET & 67 & 0.9 & 1.6 & $\mathrm{R} 2$ & ORLY & 90 & 1.3 & 2.3 & R3 \\
\hline CARCASSONNE & 130 & 2.8 & 4.9 & $\mathrm{R} 4$ & PAU & 183 & 1.4 & 2.5 & R3 \\
\hline CAZAUX & 24 & 0.7 & 1.3 & $\mathrm{R} 2$ & PERPIGNAN & 47 & 3.7 & 6.6 & $\mathrm{R} 5$ \\
\hline CHAMBERY-AIX-LES-BAI & 235 & 1.9 & 3.4 & $\mathrm{R} 4$ & POITIERS-BIARD & 120 & 1.1 & 2.0 & R3 \\
\hline CHARLEVILLE & 148 & 0.9 & 1.6 & $\mathrm{R} 2$ & QUIMPER & 94 & 0.6 & 1.1 & $\mathrm{R} 2$ \\
\hline CHARTRES & 156 & 1.7 & 3.0 & $\mathrm{R} 4$ & REIMS-PRUNAY & 96 & 0.6 & 1.1 & $\mathrm{R} 2$ \\
\hline CHATEAURROUX DEOLS & 157 & 0.6 & 1.0 & $\mathrm{R} 2$ & RENNES & 43 & 0.6 & 1.1 & $\mathrm{R} 2$ \\
\hline CLERMONT-FERRAND & 330 & 1.1 & 2.0 & $\mathrm{R} 3$ & ROISSY & 112 & 1.3 & 2.3 & $\mathrm{R} 3$ \\
\hline COGNAC & 31 & 0.6 & 1.1 & $\mathrm{R} 2$ & ROUEN & 156 & 0.9 & 1.7 & R3 \\
\hline L ORIENT LANN BIHOU & 42 & 0.9 & 1.7 & R3 & TARBES-OSSUN & 364 & 4.7 & 8.3 & R5 \\
\hline LA ROCHELLE & 10 & 0.3 & 0.6 & $\mathrm{R} 1$ & TOULOUSE BLAGNAC & 154 & 0.7 & 1.3 & $\mathrm{R} 2$ \\
\hline LA ROCHE-SUR-YON & 90 & 0.8 & 1.4 & $\mathrm{R} 2$ & TOURS & 112 & 0.9 & 1.6 & $\mathrm{R} 2$ \\
\hline LE LUC & 82 & 0.6 & 1.1 & $\mathrm{R} 2$ & TOUSSUS LE NOBLE & 161 & 1.3 & 2.3 & R3 \\
\hline LE MANS & 52 & 0.9 & 1.6 & $\mathrm{R} 2$ & TREMUSON-ST-BRIEUC & 138 & 1.7 & 3.0 & $\mathrm{R} 4$ \\
\hline LE PUY & 833 & 1.7 & 3.0 & $\mathrm{R} 4$ & TROYES BARBEREY & 118 & 1.6 & 2.8 & $\mathrm{R} 4$ \\
\hline LILLE LESQUI & 52 & 2.0 & 3.6 & $\mathrm{R} 4$ & VICHY & 251 & 1.2 & 2.1 & $\mathrm{R} 3$ \\
\hline LIMOGES & 402 & 1.7 & 3.0 & $\mathrm{R} 4$ & & & & & \\
\hline
\end{tabular}

authors to simulate noticeable loads; i.e. 133 loads greater than $1 \mathrm{~kg} \mathrm{~m}^{-1}$ recorded in 82 weather stations located in plains that could have been associated with real damages observed and recorded in a dedicated database.

Then, for each station, all simulated events during the last 25 winters have been used to estimate the $90 \%$ confidence intervals of 50-year return-period wet-snow loads. As only one ISO IC value could be found in each interval, a unique ISO IC has been determined this way for each station.
The distribution of the 87 wet-snow loads on a French map has shown that areas concerned by heavy characteristic loads had already been affected by noticeable events that happened before the last 25 winters used to calculate the 87 characteristic 50-year return-period loads.

Nevertheless, it is prudent to underline the fact that the 50-year return-period wet-snow load calculated at a specific weather station can only be considered as being available in 
the vicinity of that station; i.e. in a circle of about $50 \mathrm{~km}$ in the diameter centred at the station.

Thus, the method described in that paper can essentially be used to check that a wet-snow design load map, based on experience or on long-term applications with positive results, can be effectively related to 50-year return-period wet-snow loads in the vicinity of many weather stations.

Acknowledgements. The authors gratefully thank Bodo Wichura for the quality of his review, Svein Fikke for his heartening short comments on the NHESSD website, Cédric Josz for his advice and deep review before submission, Samir Issad for his help with Fig. 4, Michel Leclère for supplying precious old reports, Gérard Gobaut for maintaining and supplying the French event database and Serge Blumental for his advice and support.

Edited by: T. Glade

Reviewed by: B. Wichura and one anonymous referee

\section{References}

Admirat, P., Sakamoto, Y., and De Goncourt, B.: Calibration of a snow accumulation model based on actual cases in Japan and France, Proc. 4th International Workshop on Atmospheric Icing of Structures, 5-7 September 1988, Paris, France, 1988.

Barthazy, E. and Schefold, R.: Fall velocity of snowflakes of different riming degree and crystal types, Atmos. Res., 82, 391-398, 2006.

Böhm, H. P.: A general equation for the terminal fall speed of solid hydrometeors, J. Atmos. Sci., 46, 2419-2427, 1989.

Deneau, V. and Guillot, P.: Wet-snow accretion on power lines: cartographic examination of risks throughout France, La Houille Blanche, 6, 465-474, 1984.

Elíasson, A. J., Thorsteins, E., and Ólafsson, H.: Study of wetsnow events on the south coast of Iceland, Proc. 9th International Workshop on Atmospheric Icing of Structures, 5-8 June 2000, Chester, England, 2000.

Elíasson, A. J., Ágústsson, H., Hannesson, G. M., and Thorsteins, E.: Modeling wet-snow accretion: Comparison of cylindrical model to field measurements, Proc. 15th International Workshop on Atmospheric Icing of Structures, 8-13 September 2013, Newfoundland and Labrador, Canada, 2013.

EN 50341-1: Overhead electrical lines exceeding AC 1 kV - Part 1: General requirements - Common specifications, European Committee for Electrotechnical Standardization, 2012.

Goodison, B. E.: Accuracy of Canadian snow gage measurements, J. Appl. Meteorol., 17, 1542-1548, 1978.

Goodison, B. E., Louie, P. Y. T., and Yang, D.: Report no. 67: WMO solid precipitation measurement intercomparison - Final report, World Meteorological Organization, Geneva, 1998.

Hosking, J. R. M.: L-moments: analysis and estimation of distributions using linear combinations of order statistics, J. Roy. Stat. Soc. B, 52, 105-124, 1990.

ISO 12494: Atmospheric icing of structures, International Standard Organization, 2001

Kasperski, M.: Discussion of "Exceptional snowfalls and the assessment of accidental loads for structural design" by Sadovsky et al. [Cold Regions Science and Technology 72 (2012) 17-22], Cold Regi. Sci. Technol., 101, 83-86, 2014.

Leroy, M.: La mesure au sol de la température et des précipitations, La Météorologie, 39, 52-56, 2002.

Makkonen, L.: Estimation of wet-snow accretion on structures, Cold Reg. Sci. Technol., 17, 83-88, 1989.

Makkonen, L. and Wichura, B.: Simulating wet-snow loads on power line cables by a simple model, Cold Reg. Sci. Technol., 61, 73-81, 2010.

Matsuo, T., Sasyo, Y., and Sato, Y.: Relationship between types of precipitation on the ground and surface meteorological elements, J. Meteorol. Soc. Jpn., 54, 462-475, 1981

Mazingarbe, E.: Lignes aériennes - Tenue aux surcharges importantes d'origine météorologique - Givre, verglas, neige collante - Zones à risques, internal document of Electricité de France, Paris, 1987.

Muramoto, K. I., Matsuura, K., Harimaya, T., and Endoh, T.: A computer database for falling snowflakes, Ann. Glaciol., 18, 11-16, 1993.

Nygaard, B. E., Ágústsson, H., and Somfalvi-Tóth, K.: Modeling wet-snow accretion on power lines: Improvements to previous methods using 50 years of observations, J. Appl. Meteorol. Clim., 52, 2189-2203, 2013a.

Nygaard, B. E., Fikke, S. M., Wareing, B., Seierstad, I. A., and Horsman, D.: The development of new maps for design ice loads for Great Britain, Proc. 15th International Workshop on Atmospheric Icing of Structures, 8-13 September 2013, Newfoundland and Labrador, Canada, 2013b.

Rasmussen, R., Baker, B., Kochendorfer, J., Myers, T., Landolt, S., Fisher, A., Black, J., Theriault, J., Kucera, P., Gochis, D., Smith, C., Nitu, R., Hall, M., Ikeda, K., and Gutmann, E.: How well are we measuring snow? The NOAA/FAA/NCAR winter precipitation test bed, B. Am. Meteorol. Soc., 93, 811-829, 2012.

Rasmussen, R. M., Vivekanandan, J., Cole, J., Myers, B., and Masters, C.: The estimation of snowfall rate using visibility, J. Appl. Meteorol., 38, 1542-1563, 1999.

Sadovský, Z., Faško, P., Mikulová, K., and Pecho, J.: Exceptional snowfalls and the assessment of accidental snow loads for structural design, Cold Reg. Sci. Technol., 72, 17-22, 2012.

Sanpaolesi, L.: Phase 1 Final Report to the European Commission, Scientific Support Activity in the Field of Structural Stability of Civil Engineering Works: Snow Loads, Department of Structural Engineering, University of Pisa, Pisa, 1998.

Strauss, B. and Magnan, J.: Cartographie des risques de givre, verglas, neige collante à partir du fichier d'observations synoptiques de la météorologie nationale, Proc. Les Lignes aériennes face à l'environnement climatique, Société des électriciens des électrotechniciens et des radioélectriciens, 25 April 1985, Gif-surYvette, 1985.

Wakahama, G.: Experimental studies of snow accretion on electric lines developed in a strong wind, J. Nat. Disast. Sci., 1, 21-33, 1979.

Yuter, S. E., Kingsmill, D. E., Nance, L. B., and Löffler-Mang, M.: Observations of precipitation size and fall speed characteristics within coexisting rain and wet-snow, J. Appl. Meteorol. Clim., 45, 1450-1464, 2006.

Zawadski, I., Jung, E., and Lee, G.: Snow studies, Part I: a study of natural variability of snow terminal velocity, J. Atmos. Sci., 67, 1591-1604, 2010. 